I-Economic Vol.4. No 1. Juni 2018

Analisis Kebutuhan Pengembangan Laboratorium .... Mawardi

\title{
ANALISIS KEBUTUHAN PENGEMBANGAN LABORATORIUM CAPITAL MARKET TERPADU PRODI PERBANKAN SYARIAH MENUJU INVESTOR KEUANGAN DI USIA MUDA FAKULTAS EKONOMI DAN BISNIS ISLAM UIN RADEN FATAH \\ PALEMBANG
}

Mawardi

mawardi_uin@radenfatah.ac.id

\begin{abstract}
Abstrak.
Penelitian ini terkait pendirian Laboratorium Capital Market terpadu secara umum bertujuan untuk mengenalkan pasar modal sejak dini pada mahasiswa, dosen dan masyarakat masyarakat umum. Pengembangan pasar modal ini terutama di Prodi Perbankan Syariah tidak hanya bagi mahasiswa Fakultas Ekonomi dan Bisnis Islam itu sendiri melainkan juga diharapkan agar penerapannya menyeluruh untuk semua jurusan.Alumni dari FEBI sendiri dapat menjadi industri pasar modal.Apalagi, saat ini cukup banyak alumni FEBI yang telah memiliki penghasilan yang cukup.Bahkan, mahasiswa yang menjalani semester akhir juga telah memiliki sponsor sehingga, memiliki uang lebih. Daripada dipergunakan untuk berfoya-foya.Lebih baik berinvestasi. Pengembangan laboratorium CapitalMarket terpadu merupakan kunci dalam memperbesar minat generasi muda dalam berinvestasi di pasar modal.Saat ini belum banyak yang tahu bahwa berinvestasi di pasar modal tidak serumit yang dibayangkan.Memulai berinvestasi di pasar modal juga relatif terjangkau bagi kalangan mahasiswa.

Penelitian ini menggunakan metode penelitian dan pengembangan atau Research and Development $(R \& D)$. Metode penelitian dan pengembangan digunakan untuk menghasilkan produk tertentu dan menguji keefektifan produk tersebut.Penelitian dan pengembangan adalah suatu proses atau langkah-langkah untuk mengembangkan suatu produk baru atau menyempurnakan produk yang telah ada yang dapat dipertanggungjawabkan. Berdasarkan pendapat tersebut dapat disimpulkan bahwa penelitian dan pengembangan (Research and Development) adalah metode penelitian yang menghasilkan suatu produk baru melalui proses pengembangan. Produk yang dikembangkan dapat berupa produk baru ataupun menyempurnakan produk yang telah ada.

Hasil penelitian dapat dikemukakan simpulan sebagai berikut :Analisis Kebutuhan terhadap media pembelajaran capital market bagi mahasiswa dan dosen menginginkan media tersebut menjadi Menarik, yaitu disertai dengan gambar dan musik pengiring, Materi yang disajikan di dalam media disesuaikan dengan kebutuhan dan kompetensi dasar yang dipelajari mahasiswa dengan penyajian yang singkat dan jelas; dan Adanya contoh penerapan dan soal evaluasi. Pengembangan Laboratorium Capital Market terpadu melalui pembuatan program yang bekerjasama dengan pihak Danareksa sekuritas, pembentukan Galeri Investasi bekerjasama dengan pihak Bursa Efek Indonesia dan pembuatan modul.
\end{abstract}

Kata Kunci; Laboratorium Capital Market, Investasi, Investor Keuangan. 
I-Economic Vol.4. No 1. Juni 2018

Analisis Kebutuhan Pengembangan Laboratorium .... Mawardi

\section{PENDAHULUAN}

Setiap orang dihadapkan pada berbagai pilihan dalam menentukan proporsi dana atau sumber daya yang mereka miliki untuk konsumsi saat ini dan di masa datang. Investasi dapat diartikan sebagai komitmen untuk menanamkan sejumlah dana pada saat ini dengan tujuan memperoleh keuntungan di masa datang. Dengan kata lain, investasi merupakan komitmen untuk mengorbankan konsumsi sekarang (sacrifice current consumption) dengan tujuan memperbesar konsumsi di masa datang. Investasi dapat berkaitan dengan penanaman sejumlah dana pada asset real seperti tanah, emas, rumah dan asset real lainnya atau pada asset finansial seperti deposito, saham, obligasi dan surat berharga lainnya. ${ }^{1}$

Tingkat pemahaman (literasi) masyarakat Indonesia terhadap pasar modal dan tingkat utilitas produk pasar modal masih sangat rendah dan yang terkecil dibandingkan dengan 5 industri jasa keuangan lainnya. Berikut ini grafik kondisi Pasar Modal Indonesia :

Grafik 1. Kondisi Pasar Modal Indonesia

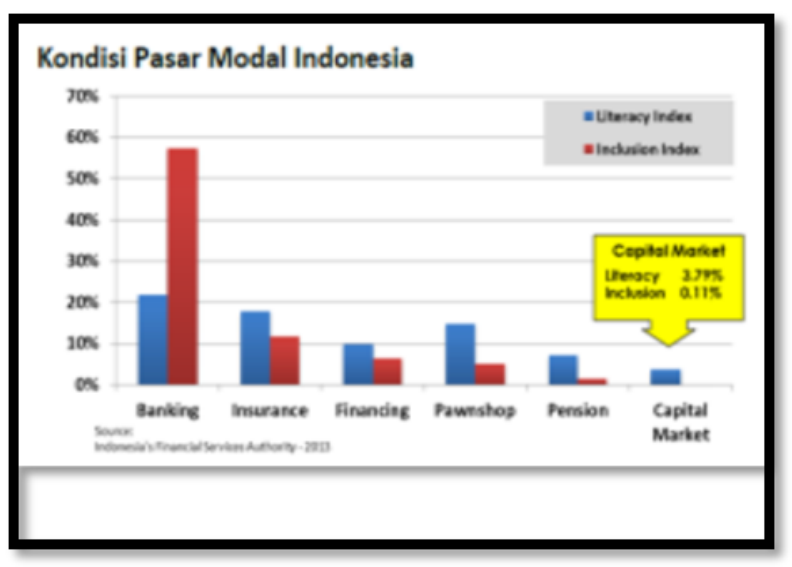

Sumber : www.idx.co.id

Berdasarkan data dari Bursa Efek Indonesia tahun 2016 bahwa jumlah investor berusia 26-30 tahun mencapai 4.573 orang, kemudian untuk usia di bawahnya yakni 21-25 tahun mencapai 2.187 orang, dan usia 17-20 tahun 853 orang. Sedangkan, usia 31-35 tahun berjumlah1.745 orang, usia 36-40 tahun 2.705 orang, usia 41-45 tahun 1.719 orang, dan usia 46-50 tahun 1.425 orang. Berdasarkan data baru Bursa Efek Indonesia (BEI), tenaga kerja muda dengan usia 26-30 tahun masih mendominasi investor di pasar modal tanah air sebanyak 30\%. Jumlah investor pasar modal Indonesia masih sedikit

\footnotetext{
${ }^{1}$ Tandelilin, Portofolio dan Investasi, Teori dan Aplikasi, Edisi Pertama, Penerbit Kanisius, 2010, h.1
} 
I-Economic Vol.4. No 1. Juni 2018

Analisis Kebutuhan Pengembangan Laboratorium .... Mawardi

yakni hanya sekitar 400.000 orang dari jumlah penduduk yang mencapai 270 juta jiwa.Sementara, Malaysia sudah mencapai 4 juta investor atau 13 persen dari populasi dan Singapura memiliki 1,5 juta investor atau 30 persen dari populasi. ${ }^{2}$

Grafik 2

Jumlah Investor di Indonesia

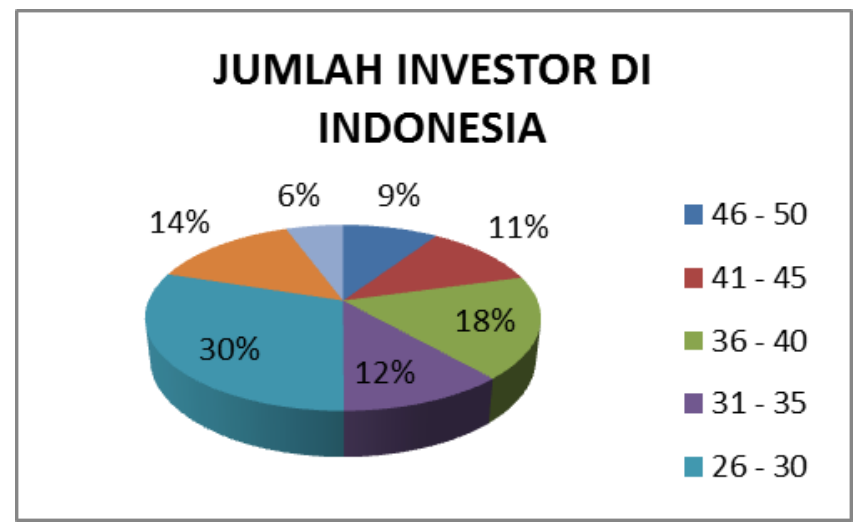

Sumber : www.idx.co.id (diolah penulis)

Generasi muda diharapkan bisa memanfaatkan investasi di pasar modal untuk menambah pundi-pundi kekayaannya.Fenomena generasi muda berinvestasi saat ini sedang meningkat. Keberadaan laboratorium capital market terpadu di Fakultas Ekonomi Bisnis Islam UIN Raden Fatah Palembang yang berperan penting untuk mengembangkan investor keuangan di usia muda. Paradigma generasi muda dalam berinvestasi pada saat ini cenderung keliru.Generasi muda masih beranggapan setelah bekerja barulah melakukan investasi.Padahal, berinvestasi harus dilakukan sejak dini.Agar hasil yang diharapkan bisa lebih maksimal.Hal itu disebabkan kurangnya sosialisasi mengenai pentingnya berinvestasi sejak muda bagi mahasiswa, bisa mempraktikkan secara langsung ilmu yang diperoleh di kampus.

Pendirian Laboratorium Capital Market terpadu secara umum bertujuan untuk mengenalkan pasar modal sejak dini pada mahasiswa, dosen dan masyarakat masyarakat umum. Pengembangan pasar modal ini terutama di Prodi Perbankan Syariah tidak hanya bagi mahasiswa Fakultas Ekonomi dan Bisnis Islam itu sendiri melainkan juga diharapkan agar penerapannya menyeluruh untuk semua jurusan.Alumni dari FEBI sendiri dapat menjadi industri pasar modal.Apalagi, saat ini cukup banyak alumni FEBI yang telah memiliki penghasilan yang

\footnotetext{
${ }^{2}$ www.idx.co.id
} 
I-Economic Vol.4. No 1. Juni 2018

Analisis Kebutuhan Pengembangan Laboratorium .... Mawardi

cukup.Bahkan, mahasiswa yang menjalani semester akhir juga telah memiliki sponsor sehingga, memiliki uang lebih. Daripada dipergunakan untuk berfoya-foya.Lebih baik berinvestasi. Pengembangan laboratorium CapitalMarket terpadu merupakan kunci dalam memperbesar minat generasi muda dalam berinvestasi di pasar modal.Saat ini belum banyak yang tahu bahwa berinvestasi di pasar modal tidak serumit yang dibayangkan.Memulai berinvestasi di pasar modal juga relatif terjangkau bagi kalangan mahasiswa.

\section{KERANGKA TEORI}

Pengertian Laboratorium Secara etimologi kata "laboratorium" berasal dari kata latin yang berarti "tempat bekerja" dan dalam perkembangannya kata "laboratorium" mempertahankan kata aslinya yaitu "tempat bekerja", akan tetapi khusus untuk keperluan penelitian ilmiah. ${ }^{3}$

Menurut kegunaannya, laboratorium dibagi menjadi dua jenis yaitu laboratorium pembelajaran (classroom laboratory) dan laboratorium penelitian (research laboratory).Laboratorium pembelajaran mempunyai ukuran yang lebih besar dari laboratorium penelitian. Laboratorium pembelajaran bisa disebut juga dengan laboratorium sekolah yang didesain untuk proses belajar mengajar, praktikum dan kegiatan lain yang mendukung proses pembelajaran. ${ }^{4}$

Pasar modal memberikan peran besar bagi perekonomian suatu negara karena pasar modal memberikan dua fungsi sekaligus yaitu fungsi ekonomi dan fungsi keuangan. Pasar modal dikatakan sebagai fungsi ekonomi karena pada pasar modal disediakan fasilitas atau wahana yang mempertemukan kepentingan yaitu pihak yang memiliki kelebihan dana (investor) dan pihak yang membutuhkan dana. Dengan adanya pasar modal, maka perusahaan publik dapat memperoleh dana dari masyarakat melalui penjualan efek saham melalui prosedur IPO atau efek utang (obligasi). ${ }^{5}$

Pengembangan adalah upaya pendidikan baik formal maupun non formal yang dilaksanakan secara sadar, berencana, terarah, teratur, dan bertanggung jawab dalam rangka memperkenalkan, menumbuhkan, membimbing, dan mengembangkan suatu dasar kepribadian yang seimbang,

\footnotetext{
${ }^{3}$ Nyoman Kertiasa, Laboratorium Sekolah dan Pengelolaannya, (Bandung: Pudak Scientific, 2006), h. 1.

${ }^{4}$ Cambridge University Press, Cambridge Advanced Leaner's Dictionary, (Singapore: Green Gian Press, 2008), h 799

${ }^{5}$ Abdul Manan, Aspek Hukum Dalam Penyelenggaraan Investasi di Pasar Modal, Jakarta: Kencana Prenada Media Group, 2009, h. 14
} 
I-Economic Vol.4. No 1. Juni 2018

Analisis Kebutuhan Pengembangan Laboratorium .... Mawardi

utuh dan selaras, pengetahuan dan ketrampilan sesuai dengan bakat, keinginan serta kemampuan-kemampuannya, sebagai bekal untuk selanjutnya atas prskarsa sendiri menambah, meningkatkan dan mengembangkan dirinya, sesame, maupun lingkungannya ke arah tercapainya martabat, mutu dan kemampuan manusiawi yang optimal dan prbadi yang mandiri. ${ }^{6}$

\section{TINJAUAN KEPUSTAKAAN}

Beberapa penelitian yang telah lebih dahulu meneliti yaitu Mulasiwi dan Santosa (2016) Hasil dari penelitian tersebut bahwa Pengembangan buku panduan praktik laboratorium bank mini Karistasari pada program keahlian akuntansi SMK N 1 Surakarta terbukti efektif untuk diterapkan sebagai acuan dalam kegiatan pembelajaran praktik sehingga mampu meningkatkan keterampilan pencatatan transaksi keuangan peserta didik. Hal tersebut ditandai dengan nilai rata-rata keterampilan peserta didik kelas ekperimen X AK mengalami kenaikan, begitu juga dengan nilai rata-rata keterampilan peserta didik kelas ekperimen XI AK. Diperkuat dengan hasil uji t pada kelas X AK maupun XI AK menunjukkan bahwa terdapat perbedaan rata-rata nilai ujian praktik (keterampilan pencatatan transaksi keuangan) peserta didik sebelum menggunakan buku panduan praktik dengan setelah menggunakan buku panduan praktik. $^{7}$

Erna Hayati A.A Istri Agung Trisnawati Widyaiswara (2015) Hasil penelitian Tingkat kemampuan petugas tertinggi ada pada tahap Pra analitik yaitu persiapan pengambilan sampel air sedangkan tingkat kemampuan petugas terendah ada pada kegiatan tahap analitik dan Paska analitik yaitu kegiatan penerapan pemantapan mutu pengujian kualitas air dan melakukan pencatatan dan pelaporan sesuai standar atau peraturan berdasarkan jenis air yang diuji. ${ }^{8}$

Christian Setiawan (2015), Penelitian ini dilakukan untuk mengetahui persepsi mahasiswa Program Manajemen Keuangan terhadap keberadaan laboratorium sebagai fasilitas penunjang proses belajar. Penelitian ini juga meneliti peran Laboratorium Keuangan terhadap kinerja mahasiswa. Dengan menggunakan partial least square (pls) dan skala likert untuk

\footnotetext{
${ }^{6}$ Drs. Iskandar Wiryokusumo, Msc, Drs. J. Mandilika, Ed, Kumpulan-KumpulanPemikiran dalamPendidikan (Jakarta: CV. Rajawali, 2004),h.93

${ }^{7}$ Mulasiwi, Santosa, Pengembangan buku panduan praktik Laboratorium Bank Mini dalam rangka meningkatkan keterampilan pencatatan transaksi keuangan pada program keahlian Akuntansi, Jurnal Pendidikan Insan Mandiri Vol 1 No 1 (2016).h. 30-43

${ }^{8}$ Erna Hayati A.A Istri Agung Trisnawati Widyaiswara (2015), Analisis Kebutuhan pelatihan bagi petugas laboratorium penguji kualitas air dinas kesehatan kabupaten / kota se-Provinsi Nusa Tenggara Barat Tahun 2015, ISSN No. 1978-3787 Media Bina Ilmiah 1 http://www.lpsdimataram.com Volume 9, No. 2, April 2015
} 
I-Economic Vol.4. No 1. Juni 2018

Analisis Kebutuhan Pengembangan Laboratorium .... Mawardi

melihat persepsi mahasiswa.Populasi atau responden dari penelitian ini adalah mahasiswa aktif Program Manajemen Keuangan periode genap tahun ajaran 2013/2014 sebanyak 211 mahasiswa. Hasil penelitian menunjukkan bahwa keberadaan Laboratorium Keuangan menunjang proses belajar mengajar. Laboratorium Pasar Modal dan Laboratorium Simulasi Keuangan memiliki peran positif terhadap kinerja mahasiswa. Sedangkan, Laboratorium Perancangan Produk Keuangan dan Investasi tidak memiliki peran yang signifikan terhadap kinerja mahasiswa. ${ }^{9}$

Penelitian yang dilakukan rai sujanem (2015) mengenai analisis kebutuhan pengembangan model pro-bbl untuk meningkatkan keterampilan berpikir kritis siswa dalam pembelajaran fisika sma menjelaskan bahwa 1) Produk kegiatan studi literatur adalah (a) daftar konsepkonsep suhu dan kalor esensial, (b) karakteristik model Pro-BBL meliputi, dasar teori, tujuan, sintaks, dan lingkungan belajar. 2) Produk kegiatan studi lapangan adalah (a) daftar konsep-konsep esensial yang telah dikaji sesuai dengan yang tertuang dalam literatur, namun belum diterapkan untuk meningkatkan keterampilan berpikir kritis dan kemampuan pemecahan masalah, (b) daftar alat lab dan ICT yang tersediacukup memadai, namun belum tersedia media web yang mewadahi model Pro-BBL, (c) daftar referensi sebagai sumber belajar cukup memadai, namun belum tersedia referensi yang bermuatan keterampilan berpikir kritis dan kemampuan pemecahan masalah, (d) metode yang biasa diterapkan guru adalah metode diskusi, ceramah, dan kadangkadang kooperatif, PBL dan Web, (e) kendala-kendala dalam PBL dan web adalah masalah waktu relatif lama, sulit menyiapkan masalah ill-structure, hanya kelompok tertentu yang bisa memecahkan masalah, akses internet lambat, dan belum ada rujukan mana web yang inovatif. ${ }^{10}$

\section{METODOLOGI PENELITIAN}

Penelitian ini menggunakan metode penelitian dan pengembangan atau Research and Development (R\&D).Metode penelitian dan pengembangan digunakan untuk menghasilkan produk tertentu dan menguji keefektifan produk tersebut.Penelitian dan pengembangan adalah suatu proses atau langkah-langkah untuk mengembangkan suatu produk baru atau menyempurnakan produk yang telah ada yang dapat dipertanggungjawabkan. Berdasarkan

\footnotetext{
${ }^{9}$ Christian Setiawan, Persepsi Mahasiswa Program Manajemen Keuangan Terhadap Keberadaan Laboratorium Sebagai Fasilitas Penunjang Proses Belajar Mengajar,Universitas Kristen Petra FINESTA Vol. 3, No. 1, (2015) 3640

${ }^{10}$ Rai sujinam.Proceedings Seminar Nasional FMIPA UNDIKSHA V Tahun 2015
} 
I-Economic Vol.4. No 1. Juni 2018

Analisis Kebutuhan Pengembangan Laboratorium .... Mawardi

pendapat tersebut dapat disimpulkan bahwa penelitian dan pengembangan (Research and Development) adalah metode penelitian yang menghasilkan suatu produk baru melalui proses pengembangan. Produk yang dikembangkan dapat berupa produk baru ataupun menyempurnakan produk yang telah ada. ${ }^{11}$

\section{LANDASAN TEORI}

\section{LABORATORIUM}

Pengertian Laboratorium Secara etimologi kata "laboratorium" berasal dari kata latin yang berarti "tempat bekerja" dan dalam perkembangannya kata "laboratorium" mempertahankan kata aslinya yaitu "tempat bekerja", akan tetapi khusus untuk keperluan penelitian ilmiah. ${ }^{12}$

Pengertian lain dMenurut A S Hornby, laboratory is a room or building used scientific research, experiments, testing, etc. ${ }^{13}$ Laboratorium adalah ruangan atau bangunan yang digunakan penelitian ilmiah, eksperimen, pengujian dan lain - lain.Menurut Kamus Cambridge Advanced Leaner's Dictionary, laboratorium atau laboratory is a room or building with scientific equipment for teaching science, or a place where chemicals or medicines produced. ${ }^{14}$ Laboratorium adalah ruang atau bangunan dengan peralatan ilmiah untuk melakukan tes ilmiah atau untuk mengajar ilmu pengetahuan, atau tempat dimana bahan kimia atau obat-obatan yang diproduksi.

\section{PASAR MODAL (Capital Market)}

Pasar modal adalah pertemuan antara pihak yang memiliki kelebihan dana dengan pihak yang membutuhkan dana dengan cara memperjualbelikan sekuritas. Dengan demikian, pasar modal juga bisa diartikan sebagai pasar untuk memperjualbelikan sekuritas yang umumnya memiliki umur lebih dari satu tahun, seperti saham dan obligasi. ${ }^{15}$. Investasi di pasar modal atau bursa efek memang lebih berisiko dibandingkan dengan investasi tabungan dan deposito.Investor membeli produk keuangan di pasar modal karena ingin mendapatkan keuntungan yang lebih besar daripada yang didapatkan dari tabungan dan deposito.Pasar modal memberikan peran besar

\footnotetext{
${ }^{11}$ Sugiyono. Metode Penelitian Kuantitatif Kualitatif dan R\&D. Bandung: Alfabeta.2012, h. 407

${ }^{12}$ Nyoman Kertiasa, Laboratorium Sekolah dan Pengelolaannya, (Bandung: Pudak Scientific, 2006), h. 1.

${ }^{13}$ A S Hornby, Oxford Advanced Leaner's Dictionary, (Oxford University Press, 2010), cet-8, h 829

${ }^{14}$ Cambridge University Press, Cambridge Advanced Leaner's Dictionary, (Singapore: Green Gian Press, 2008), h 799

${ }^{15}$ Tandelilin, Portofolio dan Investasi, Teori dan Aplikasi, Edisi Pertama, Penerbit Kanisius, 2010, h.26
} 
bagi perekonomian suatu negara karena pasar modal memberikan dua fungsi sekaligus yaitu fungsi ekonomi dan fungsi keuangan. Pasar modal dikatakan sebagai fungsi ekonomi karena pada pasar modal disediakan fasilitas atau wahana yang mempertemukan kepentingan yaitu pihak yang memiliki kelebihan dana (investor) dan pihak yang membutuhkan dana. Dengan adanya pasar modal, maka perusahaan publik dapat memperoleh dana dari masyarakat melalui penjualan efek saham melalui prosedur IPO atau efek utang (obligasi). ${ }^{16}$

Tabel 1. Instrumen Investasi di Pasar Modal

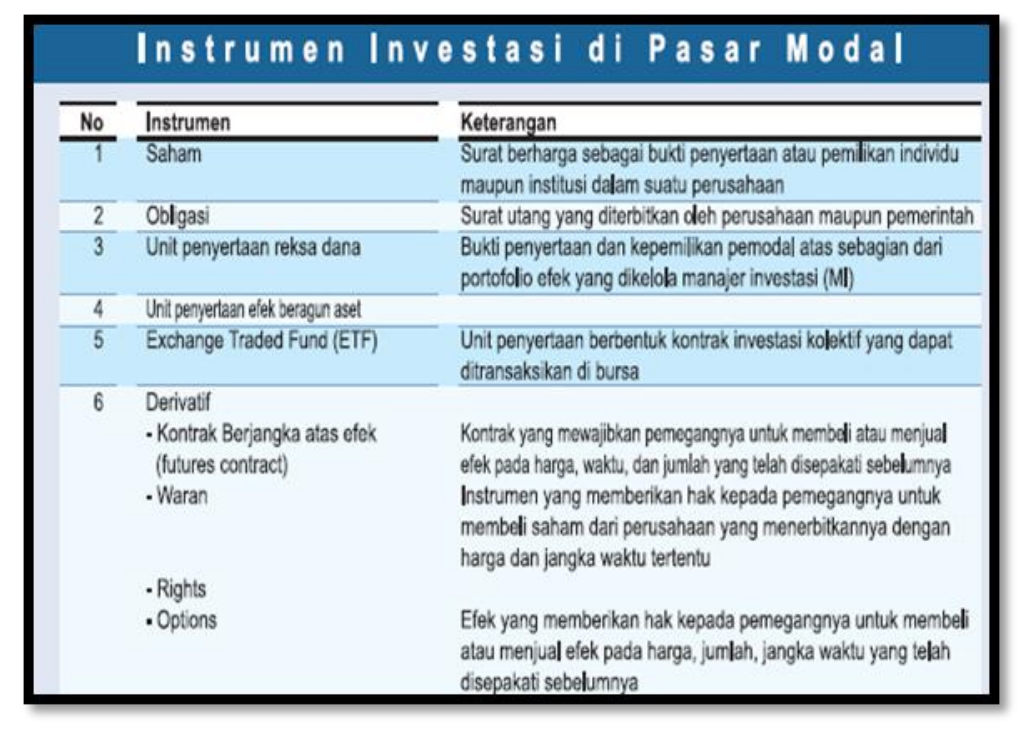

Sumber :Investor Daily,Oktober-November 2011

\section{PENGEMBANGAN}

Pengembangan pembelajaran adalah suatu proses mendesain pembelajaran secara logis, dan sistematis dalam rangka untuk menetapkan segala sesuatu yang akan dilaksanakan dalam proses kegiatan belajar dengan memperhatikan potensi dan kompetensi siswa. ${ }^{17}$ Model pengembangan yang digunakan dalam penelitian ini adalah model dari Dick \& Carey yaitu: ${ }^{18}$ (1). Identifikasi Tujuan Pembelajaran, (2). Analisis Pembelajaran (3). Analisis Pembelajar dan Konteks, (4).

\footnotetext{
${ }^{16}$ Abdul Manan, Aspek Hukum Dalam Penyelenggaraan Investasi di Pasar Modal, Jakarta: Kencana Prenada Media Group, 2009, h. 14

${ }^{17}$ Abdul majid, Perencanaan Pembelajaran (mengembangkan kompetensi guru, Remaja Rosdakarya, Bandung, 2005, h. 24

${ }^{18}$ Dick, W. dan Carey, L. 1985.The Systematic Design of Instruction. USA: Harper Collins Publisher, 2009, h 6 -8
} 
I-Economic Vol.4. No 1. Juni 2018

Analisis Kebutuhan Pengembangan Laboratorium .... Mawardi

Menentukan Tujuan Pembelajaran (5). Mengembangkan Instrumen Penilaian (6). Mengembangkan Strategi Pembelajaran (7). Mengembangkan dan Memilih Bahan Pembelajaran (8).Mendesain dan Melakukan Evaluasi Formatif (9).Revisi (10).Mendesain dan Melakukan Evaluasi Sumatif.

\section{F. Kerangka Konseptual}

Dari berbagai pengembangan model diatas dapat dikembangkan kerangka konseptualpengembangan Laboratorium Capital Market Terpadu Perbankan Syariah yang diadaptasi dari Dick \& Carey. Berikut gambaran kerangka konseptual :

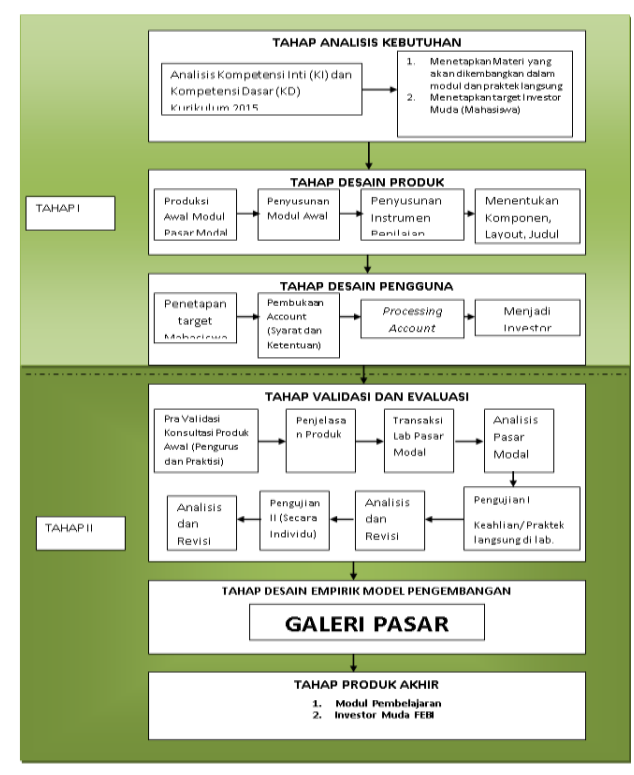

Gambar 1 : Kerangka konseptual pengembangan Laboratorium Capital Market Terpadu Perbankan Syariah (diolah penulis dan diadaptasi dari Dick \& Carey, 2009)

\section{G. Tahap Analisis Kebutuhan}

Tahap ini bertujuan untuk mengkaji tujuan dari produk yang akan dikembangkan. Peneliti akan melakukan analisis kurikulum untuk menentukan produk yang sesuai dengan tuntutan kurikulum. Analisis kurikulum akan menghasilkan tema yang disesuaikan dengan Kompetensi Isi dan Kompetensi Dasar. Selain itu, tahap ini akan menentukan dan menetapkan modul yang akan dikembangkan dalam satu satuan program tertentu. Satuan program dapat diartikan sebagai satu tahun pelajaran, satu semester, atau hanya satu standar kompetensi. 
I-Economic Vol.4. No 1. Juni 2018

Analisis Kebutuhan Pengembangan Laboratorium .... Mawardi

\section{PEMBAHASAN}

\section{Analisis kebutuhan Laboratorium Capital Market terpadu Prodi Perbankan Syariah} Fakultas Ekonomi dan Bisnis Islam UIN Raden Fatah Palembang

Hasil analisis kebutuhan Laboratorium capital market terpadu menjadi acuan dalam pengembangan model Laboratorium ini diperoleh berdasarkan analisis kebutuhan mahasiswa dan dosen terhadap media pembelajaran Capital Market berbasis online untuk meningkatkan penguasaan Pasar Modalmahasiswa Fakultas Ekonomi dan Bisnis Islam UIN Raden Fatah. Berikut ini pemaparan hasil analisis kebutuhan mahasiswa dan dosen terhadap pembelajaran Laboratorium Pasar Modal.

\section{a. Analisis Kebutuhan Mahasiswa terhadap laboratorium Pasar Modal terpadu}

Kebutuhan mahasiswa terhadap media laboratorium Pasar Modal berbasis on line untuk mahasiswa meliputi: (1) pemahaman awal tentang Pasar Mosal, (2) kebutuhan adanya media pembelajaran Pasaar Modal (3) kebutuhan isi atau materi media pembelajaran Pasar Modal(4) komunikasi visual (tampilan), (5) kebutuhan fisik media pembelajaranPasar Modal, dan (6) harapan terhadap media pembelajaran Pasar Modal. Berikut ini adalah pemaparan dari keenam aspek kebutuhan mahasiswa terhadap media pengembangan laboratorium Pasar Modal.

\section{1) Pemahaman Awal Terhadap Pasar Modal}

Tanggapan mahasiswa mengenai Pasar Modal dapat dilihat pada tabel berikut.

Tabel 2 Pentingnya Laboratorium Pasar Modaldan Tanggapan Responden

\begin{tabular}{|c|c|c|}
\hline No & Tanggapan Mahasiswa & Jumlah \\
\hline 1 & Sangat penting & 50 \\
\hline 2 & Penting & 40 \\
\hline 3 & Cukup penting & 7 \\
\hline 4 & Kurang penting & 3 \\
\hline 5 & Tidak penting & - \\
\hline
\end{tabular}

Sumber : diolah penulis, 2017

Berdasar pada kenyataan tersebut, peneliti mencoba untuk mengembangkan media lain yang lebih menarik untuk membantu mahasiswa mempelajari Pasar Modal. Diharapkan media ini dapat membantu meningkatkan penguasaan tentang Pasar Modal dan memberikan kemudahan dalam mempelajari Pasar Modal. 
I-Economic Vol.4. No 1. Juni 2018

Analisis Kebutuhan Pengembangan Laboratorium .... Mawardi

\section{2) Kebutuhan Adanya Media Laboratorium Pasar Modal}

Tanggapan mahasiswa terhadap aspek kebutuhan adanya media pembelajaran laboratorium Pasar Modal dapat dilihat pada table 3 berikut

\section{Tabel 3. Kebutuhan adanya laboratorium Pasar Modal}

\begin{tabular}{|c|c|c|c|c|}
\hline Indikator & Pertanyaan & Pilihan Jawaban & Jumlah Jawaban & Jumlah Mahasiswa \\
\hline $\begin{array}{lr}\text { Ketersediaan } & \text { media } \\
\text { pembelajaran } & \text { laboratorium } \\
\text { Pasar Modal } & \\
\end{array}$ & $\begin{array}{ll}\text { Pendapat } & \text { anda } \\
\text { mengenai } & \\
\text { ketersediaan } & \text { media } \\
\text { pembelajaran } & \\
\text { laboratorium } & \text { Pasar } \\
\text { Modal } & \end{array}$ & $\begin{array}{l}\text { - Sangat memadai } \\
\text { - Memadai } \\
\text { - Cukup memadai } \\
\text { - Kurang memadai } \\
\text { - Tidak memadai }\end{array}$ & $\begin{array}{l}15 \\
20 \\
25 \\
35 \\
5\end{array}$ & 100 \\
\hline $\begin{array}{l}\text { Tanggapan terhadap media } \\
\text { pembelajaran laboratorium } \\
\text { Pasar Modal }\end{array}$ & $\begin{array}{l}\text { Bagaimana } \\
\text { tanggapan anda } \\
\text { terhadap adanya } \\
\text { media pembelajaran } \\
\text { laboratorium Pasar } \\
\text { Modal }\end{array}$ & $\begin{array}{l}\text { - Sangat setuju } \\
\text { - Setuju } \\
\text { - Cukup Setuju } \\
\text { - Kurang setuju } \\
\text { - Tidak setuju }\end{array}$ & $\begin{array}{l}63 \\
34 \\
3 \\
- \\
-\end{array}$ & 100 \\
\hline
\end{tabular}

Sumber : diolah penulis, 2017

Media yang akan dikembangkan peneliti nantinya diharapkan dapat menambah keberadaan media sebagai sarana mempelajari Pasar Modal sehingga muncul ketertarikan dan keinginan dari mahasiswa untuk mempelajari Pasar Modal.

\section{3) Kebutuhan Isi atau Materi Media Pembelajaran Pasar Modal}

Analisis kebutuhan isi media pembelajaran interaktif ini merupakan gambaran substansi (isi) yang terdapat dalam media pembelajaran laboratorium Pasar Modal.Adanya kebutuhan isi media merupakan langkah peneliti dalam menentukan dan mengemas pemaparan materi laboratorium Pasar Modal, contoh-contoh, dan evaluasi. Aspek kebutuhan isi atau materi di dalam media pembelajaran Pasar Modal ini terdiri atas enam indikator, yaitu (1) cara penyampaian atau pemaparan materi, (2) materi pemakaian laboratorium Pasar Modal(3) materi onlinePasar Modal, (4) materi analisis laboratorium Pasar Modal (5) keberadaan contoh kasus, dan (6) adanya evaluasi atau penilaian. Untuk memperoleh gambaran tentang kebutuhan isi atau materi media pembelajaran interaktif Laboratorium Pasar Modaldapat dilihat pada tabel 4 berikut.

Tabel 4 Kebutuhan Isi atau Materi Media Pembelajaran Pasar Modal

\begin{tabular}{|c|c|c|c|c|}
\hline Indikator & Pertanyaan & Pilihan Jawaban & Jumlah & $\begin{array}{c}\text { Jumlah } \\
\text { Mahasiswa }\end{array}$ \\
\hline
\end{tabular}


I-Economic Vol.4. No 1. Juni 2018

Analisis Kebutuhan Pengembangan Laboratorium .... Mawardi

\begin{tabular}{|c|c|c|c|c|}
\hline \multirow{3}{*}{$\begin{array}{c}\text { Penyampaian atau pemaparan } \\
\text { materi }\end{array}$} & \multirow{3}{*}{$\begin{array}{l}\text { Cara penyampaian } \\
\text { materi yang anda } \\
\text { inginkan? }\end{array}$} & Singkat dan jelas & 65 & \multirow[t]{3}{*}{100} \\
\hline & & $\begin{array}{c}\text { Uraian sejelas - } \\
\text { jelasnya }\end{array}$ & 35 & \\
\hline & & Jawaban lain & - & \\
\hline \multirow{3}{*}{$\begin{array}{l}\text { Materi aplikasi saham top di } \\
\text { Pasar Modal }\end{array}$} & \multirow{3}{*}{$\begin{array}{c}\text { Apakah materi tentang } \\
\text { saham top di Pasar } \\
\text { Modal perlu } \\
\text { disampaikan semua? }\end{array}$} & $\mathrm{Ya}$ & 60 & \multirow[t]{3}{*}{100} \\
\hline & & Tidak & 17 & \\
\hline & & $\begin{array}{c}\text { Disesuaikan dengan } \\
\text { kebutuhan mahasiswa }\end{array}$ & 23 & \\
\hline \multirow[t]{3}{*}{ Materi online Pasar Modal } & \multirow{3}{*}{$\begin{array}{c}\text { Apakah materi } \\
\text { laboratorium Pasar } \\
\text { Modal online perlu } \\
\text { disampaikan semua? }\end{array}$} & $\mathrm{Ya}$ & 50 & \multirow[t]{3}{*}{100} \\
\hline & & Tidak & 10 & \\
\hline & & $\begin{array}{c}\text { Disesuaikan dengan } \\
\text { kebutuhan mahasiswa }\end{array}$ & 40 & \\
\hline \multirow{3}{*}{$\begin{array}{l}\text { Materi Analisis Saham di } \\
\text { Pasar Modal }\end{array}$} & \multirow{3}{*}{$\begin{array}{c}\text { Apakah materi tentang } \\
\text { analisis saham Pasar } \\
\text { Modal perlu diampaikan } \\
\text { semua }\end{array}$} & $\mathrm{Ya}$ & 85 & \multirow[t]{3}{*}{100} \\
\hline & & Tidak & - & \\
\hline & & $\begin{array}{c}\text { Disesuaikan dengan } \\
\text { kebutuhan mahasiswa }\end{array}$ & 15 & \\
\hline \multirow[t]{3}{*}{ Adanya contoh } & \multirow{3}{*}{$\begin{array}{c}\text { Apakah diperlukan } \\
\text { contoh setelah } \\
\text { penyampaian materi }\end{array}$} & Sangat perlu & 75 & \multirow[t]{3}{*}{100} \\
\hline & & Perlu & 25 & \\
\hline & & Tidak Perlu & - & \\
\hline \multirow[t]{6}{*}{ Adanya evaluasi } & \multirow{3}{*}{$\begin{array}{l}\text { Apakah pada bagian } \\
\text { akhir perlu ada evaluasi }\end{array}$} & Sangat perlu & 88 & \multirow[t]{3}{*}{100} \\
\hline & & Perlu & 12 & \\
\hline & & Tidak Perlu & - & \\
\hline & \multirow{3}{*}{$\begin{array}{l}\text { Bentuk soal evaluasi } \\
\text { yang anda inginkan }\end{array}$} & Pilihan ganda & 35 & \multirow[t]{3}{*}{100} \\
\hline & & Benar Salah & 65 & \\
\hline & & Jawaban lain & - & \\
\hline
\end{tabular}

Sumber : diolah penulis, 2017

Berdasarkan hasil tersebut, maka dapat disimpulkan bahwa evaluasi diperlukan sebagai sarana untuk mengukur tingkat pemahaman mahasiswa terhadap materi yang telah disajikan. Hasil jawaban pertanyaan kedua, menunjukkan bahwa bentuk soal yang digunakan dalam evaluasi adalah benar salah. Soal yang digunakan dalam evaluasi tentunya disesuaikan dengan materi yang disajikan di dalam media pembelajaran Pasar Modal.

\section{4) Aspek Komunikasi Visual (Tampilan) Media Pembelajaran Laboratorium Pasar Modal}

Gambaran tentang aspek komunikasi visual (tampilan) media pembelajaran laboratorium Pasar Modaldapat dilihat pada tabel 5 berikut.

Tabel 5 Aspek Komunikasi visual (tampilan) media pembelajaran laboratorium Pasar

\section{Modal}

\begin{tabular}{|l|l|l|l|c|c|}
\hline No & Indikator & Pertanyaan & Pilihan Jawaban & Jumlah & Jumlah \\
\hline
\end{tabular}


I-Economic Vol.4. No 1. Juni 2018

Analisis Kebutuhan Pengembangan Laboratorium .... Mawardi

\begin{tabular}{|c|c|c|c|c|c|}
\hline & & & & Jawaban & Mahasiswa \\
\hline \multirow[t]{3}{*}{1} & \multirow[t]{3}{*}{ Tampilan Warna } & \multirow{3}{*}{$\begin{array}{l}\text { Warna yang anda inginkan } \\
\text { di dalam media } \\
\text { pembelajaran Pasar Modal }\end{array}$} & $\begin{array}{l}\text { Warna - warna cerah yang tidak } \\
\text { mengacaukan tampilan }\end{array}$ & 64 & 100 \\
\hline & & & $\begin{array}{l}\text { Warna - warna gelap yang tidak } \\
\text { mengacaukan tampilan }\end{array}$ & 33 & \\
\hline & & & Jawaban lain & 3 & \\
\hline \multirow[t]{3}{*}{2} & \multirow{3}{*}{$\begin{array}{l}\text { Adanya musik atau } \\
\text { efek suara }\end{array}$} & \multirow{3}{*}{$\begin{array}{l}\text { Apakah di dalam media } \\
\text { tersebut perlu ada music } \\
\text { pengiring }\end{array}$} & Sangat perlu & 3 & 100 \\
\hline & & & Perlu & 20 & \\
\hline & & & Tidak perlu & 77 & \\
\hline \multirow[t]{3}{*}{3} & \multirow{3}{*}{$\begin{array}{l}\text { Perlu tidaknya gambar } \\
\text { atau animasi di dalam } \\
\text { media }\end{array}$} & \multirow{3}{*}{$\begin{array}{l}\text { Apakah di dalam media } \\
\text { pembelajaran Pasar Modal } \\
\text { perlu disertai gambar atau } \\
\text { animasi }\end{array}$} & Sangat perlu & 5 & 100 \\
\hline & & & Perlu & 28 & \\
\hline & & & Tidak perlu & 67 & \\
\hline \multirow[t]{4}{*}{4} & \multirow{4}{*}{$\begin{array}{l}\text { Penggunaan huruf } \\
\text { dalam penyajian }\end{array}$} & \multirow{4}{*}{$\begin{array}{l}\text { Jenis huruf yang anda } \\
\text { inginkan } \\
\text { menyajikan materi }\end{array}$} & Comic sans MS & 4 & 100 \\
\hline & & & Tahoma & 20 & \\
\hline & & & Times New Roman & 76 & \\
\hline & & & Jawaban Lain & & \\
\hline \multirow[t]{3}{*}{5} & \multirow{3}{*}{$\begin{array}{l}\text { Ketersediaan menu } \\
\text { atau ikon untuk } \\
\text { membantu mahasiswa }\end{array}$} & \multirow{3}{*}{$\begin{array}{l}\text { Pendapat anda jika disusun } \\
\text { menu atau ikon untuk } \\
\text { membantu } \\
\text { Mahasiswa }\end{array}$} & Sangat setuju & 46 & 100 \\
\hline & & & Setuju & 54 & \\
\hline & & & Kurang setuju & - & \\
\hline
\end{tabular}

Sumber : diolah penulis, 2017

\section{5) Aspek Kebutuhan Fisik Media Pembelajaran Laboratorium Pasar Modal}

Gambaran tentang aspek kebutuhan fisik media pembelajaran interaktif Pasar Modaldapat dilihat pada tabel 6 berikut

Tabel 6 Kebutuhan Fisik Media Pembelajaran Pasar Modal

\begin{tabular}{|c|l|l|l|c|c|}
\hline No & \multicolumn{1}{|c|}{ Indikator } & \multicolumn{1}{c|}{ Pertanyaan } & $\begin{array}{c}\text { Jumlah Jumlah Jawaban } \\
\text { Jawaban } \\
\text { Mahasiswa }\end{array}$ \\
\hline 1 & $\begin{array}{l}\text { Tampilan Program } \\
\text { Trading Online Pasar } \\
\text { Modal }\end{array}$ & $\begin{array}{l}\text { Bagaimana tampilan } \\
\text { program trading online } \\
\text { Pasar Modal }\end{array}$ & $\begin{array}{l}\text { Mempelajari Pasar Modal } \\
\text { asyik dan menarik }\end{array}$ & 48 & 100 \\
\hline
\end{tabular}


I-Economic Vol.4. No 1. Juni 2018

Analisis Kebutuhan Pengembangan Laboratorium .... Mawardi

\begin{tabular}{|c|c|c|c|c|c|}
\hline & & & $\begin{array}{ll}\text { Buktikan bahwa } & \text { belajar } \\
\text { Pasar } & \text { Modal } \\
\text { menyenangkan } & \end{array}$ & 32 & \\
\hline & & & $\begin{array}{l}\text { Mudahnya berinvestasi di } \\
\text { Pasar Modal }\end{array}$ & 20 & \\
\hline & & & Jawaban lainnya & - & \\
\hline \multirow[t]{4}{*}{2} & \multirow{4}{*}{$\begin{array}{l}\text { Jenis trading online yang } \\
\text { digunakan }\end{array}$} & \multirow{4}{*}{$\begin{array}{l}\text { Jenis Trading online } \\
\text { yang anda pilih untuk } \\
\text { digunakan }\end{array}$} & Saham & 98 & 100 \\
\hline & & & Reksadana & 2 & \\
\hline & & & Obligasi & - & \\
\hline & & & Jawaban Lainnya & - & \\
\hline \multirow[t]{4}{*}{3} & \multirow[t]{4}{*}{ Waktu Trading online } & \multirow{4}{*}{$\begin{array}{l}\text { Waktu yang digunakan } \\
\text { dalam trading online }\end{array}$} & Tepat sekali & 44 & 100 \\
\hline & & & Tepat & 22 & \\
\hline & & & Kurang Tepat & 34 & \\
\hline & & & Jawaban lain & - & \\
\hline \multirow[t]{4}{*}{4} & \multirow[t]{4}{*}{ Akun Dummy } & \multirow{4}{*}{$\begin{array}{l}\text { Apakah perlu akun } \\
\text { dummy untuk pelatihan } \\
\text { mahasiswa }\end{array}$} & Sangat perlu & 76 & 100 \\
\hline & & & Perlu & 24 & \\
\hline & & & Tidak perlu & - & \\
\hline & & & Jawaban Lain & - & \\
\hline
\end{tabular}

Sumber : diolah penulis, 2017

Berdasarkan hasil tersebut, tampilan program yang diinginkan oleh sebagian besar mahasiswa adalah Mempelajari Pasar Modal dengan Asyik dan Menarik.

\section{6) Harapan Mahasiswa terhadap Media Pembelajaran Laboratorium Pasar Modal}

Secara garis besar, harapan mahasiswa terhadap media pembelajaran Pasar Modal yaitu menarik dan dapat memotivasi mahasiswa untuk mempelajari Pasar Modal. Dari segi materi, mahasiswa menginginkan penjelasan yang singkat tetapi jelas dan tidak membingungkan. Tampilan program akan lebih menarik jika disertai dengan adanya warna - warna cerah, tidak perlu berlebihan sehingga mahasiswa tetap memperhatikan pada materi yang disajikan. Media yang dihasilkan sebaiknya dapat digunakan dalam pembelajaran mandiri sehingga mahasiswa tidak bergantung pada keberadaan dosen.

\section{Analisis Kebutuhan Dosen terhadap Media Pembelajaran Pasar Modal Berbasis Laboratorium untuk Mahasiswa Fakultas Ekonomi dan Bisnis Islam}

Kebutuhan dosen terhadap media pembelajaran Pasar Modal berbasis laboratorium untuk mahasiswa FEBI meliputi: (1) pemahaman awal tentang Pasar Modal, (2) kebutuhan adanya media pembelajaran Pasar Modal, (3) kebutuhan isi atau materi media pembelajaran Pasar Modal, (4) komunikasi visual (tampilan), (5) kebutuhan fisik media pembelajaranPasar Modal, 
I-Economic Vol.4. No 1. Juni 2018

Analisis Kebutuhan Pengembangan Laboratorium .... Mawardi

dan (6) harapan terhadap media pembelajaran Pasar Modal. Berikut ini adalah pemaparan dari keenam aspek kebutuhan dosen terhadap media pembelajaran Pasar Modal

Tabel 7 Pentingnya Pasar Modal bagi Mahasiswa

\begin{tabular}{|c|c|c|}
\hline No & Pentingnya Pasar Modal bagi Mahasiswa & Jumlah \\
\hline 1 & Sangat penting & 23 \\
\hline 2 & Penting & \\
\hline 3 & Cukup penting & \\
\hline 4 & Kurang penting & \\
\hline 5 & Tidak penting & \\
\hline
\end{tabular}

Sumber : diolah penulis, 2017

Berdasarkan tabel 7 dapat dideskripsikan bahwa dari 23 dosen yang ada , karena penguasaan Pasar Modal itu sangat penting bagi mahasiswa, maka diperlukan media yang lebih baik dan menarik bagi mahasiswa sebagai sarana untuk mempelajari Pasar Modal sehingga penguasaan Pasar Modal mahasiswa meningkat.

1) Kebutuhan Adanya Media Pembelajaran Interaktif Pasar Modal, Aspek kebutuhan adanya media pembelajaran interaktif Pasar Modal ini terdiri atas dua indikator, yaitu (1) ketersediaan media pembelajaran Pasar Modal di lapangan dan (2) tanggapan terhadap media pembelajaran interaktif Pasar Modal. Tanggapan dosen terhadap aspek kebutuhan adanya media pembelajaran interaktif Pasar Modal dapat dilihat pada tabel 8 berikut:

Tabel 8 Kebutuhan Adanya Media Pembelajaran Pasar Modal

\begin{tabular}{|c|c|c|c|c|}
\hline Indikator & Pertanyaan & Pilihan Jawaban & $\begin{array}{c}\text { Jumlah } \\
\text { Jawaban }\end{array}$ & $\begin{array}{c}\text { Jumlah } \\
\text { Dosen } \\
\end{array}$ \\
\hline \multirow[t]{2}{*}{$\begin{array}{l}\text { Ketersediaan } \\
\text { media } \\
\text { pembelajaran Pasar } \\
\text { Modal }\end{array}$} & $\begin{array}{l}\text { Apakah menurut } \\
\text { Bapak/ibu buku pasar } \\
\text { modal yang ada dapat } \\
\text { memotivasi mahasiswa } \\
\text { untuk mempelajari pasar } \\
\text { modal? }\end{array}$ & $\begin{array}{ll}- & \text { Belum } \\
- & \text { Sudah }\end{array}$ & $\begin{array}{l}3 \\
20\end{array}$ & 23 \\
\hline & $\begin{array}{lr}\text { Pendapat } & \text { Bapak/Ibu } \\
\text { mengenai } & \text { ketersediaan } \\
\text { media } & \text { pembelajaran } \\
\text { pasar modal? }\end{array}$ & $\begin{array}{ll}\text { - } & \text { Sudah memadai } \\
\text { - } & \text { Kurang memadai } \\
\text { - } & \text { Tidak Memadai }\end{array}$ & $\begin{array}{l}4 \\
19\end{array}$ & 23 \\
\hline $\begin{array}{l}\text { Tanggapan } \\
\text { terhadap media } \\
\text { pembelajaran Pasar } \\
\text { Modal }\end{array}$ & $\begin{array}{lr}\text { Bagaiman } & \text { tanggapan } \\
\text { Bapak/ibu } & \text { terhadap } \\
\text { adanya } & \text { media } \\
\text { pembelajaran } & \text { pasar } \\
\text { modal } & \\
\end{array}$ & $\begin{array}{ll}- & \text { Sangat setuju } \\
- & \text { Setuju } \\
- & \text { Tidak setuju }\end{array}$ & $\begin{array}{l}23 \\
- \\
-\end{array}$ & 23 \\
\hline
\end{tabular}

Sumber : diolah penulis, 2017

\section{2) Kebutuhan Isi atau Materi Media Pembelajaran Interaktif Pasar Modal}


I-Economic Vol.4. No 1. Juni 2018

Analisis Kebutuhan Pengembangan Laboratorium .... Mawardi

Analisis kebutuhan isi media pembelajaran interaktif Pasar Modal ini merupakan gambaran substansi (isi) yang terdapat dalam media pembelajaran interaktif Pasar Modal.Analisis terhadap kebutuhan isi atau materi ini merupakan langkah peneliti dalam mengemas pemaparan materimateri Pasar Modal, contoh-contoh, dan evaluasi. Aspek kebutuhan isi atau materi di dalam media pembelajaran interaktif Pasar Modal ini terdiri atas enam indikator, yaituyaitu (1) cara penyampaian atau pemaparan materi, (2) materi pemakaian laboratorium Pasar Modal (3) materi online Pasar Modal, (4) materi analisis laboratorium Pasar Modal (5) keberadaan contoh kasus, dan (6) adanya evaluasi atau penilaian. Gambaran tentang kebutuhan isi atau materi media pembelajaran interaktif Laboratorium Pasar Modaldapat dilihat pada tabel 9 berikut.

Tabel 9. Analisis kebutuhan isi/materi pembelajaran Pasar Modal

\begin{tabular}{|c|c|c|c|c|}
\hline Indikator & Pertanyaan & Pilihan Jawaban & $\begin{array}{c}\text { Jumlah } \\
\text { Jawaban }\end{array}$ & $\begin{array}{c}\text { Jumlah } \\
\text { Dosen }\end{array}$ \\
\hline \multirow{3}{*}{$\begin{array}{l}\text { Penyampaian atau } \\
\text { pemaparan materi }\end{array}$} & \multirow{3}{*}{$\begin{array}{c}\text { Cara penyampaian materi } \\
\text { yang anda inginkan? }\end{array}$} & Singkat dan jelas & - & \multirow[t]{3}{*}{23} \\
\hline & & $\begin{array}{c}\text { Uraian sejelas - } \\
\text { jelasnya }\end{array}$ & 20 & \\
\hline & & Jawaban lain & 3 & \\
\hline \multirow{3}{*}{$\begin{array}{l}\text { Materi aplikasi saham } \\
\text { top di Pasar Modal }\end{array}$} & \multirow{3}{*}{$\begin{array}{c}\text { Apakah materi tentang } \\
\text { saham top di Pasar Modal } \\
\text { perlu disampaikan semua? }\end{array}$} & $\mathrm{Ya}$ & 10 & \multirow[t]{3}{*}{23} \\
\hline & & Tidak & - & \\
\hline & & $\begin{array}{c}\text { Disesuaikan dengan } \\
\text { kebutuhan mahasiswa }\end{array}$ & 13 & \\
\hline \multirow{3}{*}{$\begin{array}{c}\text { Materi online Pasar } \\
\text { Modal }\end{array}$} & \multirow{3}{*}{$\begin{array}{c}\text { Apakah materi } \\
\text { laboratorium Pasar Modal } \\
\text { online perlu disampaikan } \\
\text { semua? }\end{array}$} & $\mathrm{Ya}$ & 23 & \multirow[t]{3}{*}{23} \\
\hline & & Tidak & - & \\
\hline & & $\begin{array}{c}\text { Disesuaikan dengan } \\
\text { kebutuhan mahasiswa }\end{array}$ & - & \\
\hline \multirow{3}{*}{$\begin{array}{l}\text { Materi Analisis Saham } \\
\text { di Pasar Modal }\end{array}$} & \multirow{3}{*}{$\begin{array}{c}\text { Apakah materi tentang } \\
\text { analisis saham Pasar } \\
\text { Modal perlu diampaikan } \\
\text { semua }\end{array}$} & Ya & 16 & \multirow[t]{3}{*}{23} \\
\hline & & Tidak & - & \\
\hline & & $\begin{array}{c}\text { Disesuaikan dengan } \\
\text { kebutuhan mahasiswa }\end{array}$ & 7 & \\
\hline \multirow[t]{3}{*}{ Adanya contoh } & \multirow{3}{*}{$\begin{array}{c}\text { Apakah diperlukan contoh } \\
\text { setelah penyampaian } \\
\text { materi }\end{array}$} & Sangat perlu & 15 & \multirow[t]{3}{*}{23} \\
\hline & & Perlu & 8 & \\
\hline & & Tidak Perlu & - & \\
\hline \multirow[t]{6}{*}{ Adanya evaluasi } & \multirow{3}{*}{$\begin{array}{l}\text { Apakah pada bagian akhir } \\
\text { perlu ada evaluasi }\end{array}$} & Sangat perlu & 14 & \multirow[t]{3}{*}{23} \\
\hline & & Perlu & 9 & \\
\hline & & Tidak Perlu & - & \\
\hline & \multirow{3}{*}{$\begin{array}{c}\text { Bentuk soal evaluasi yang } \\
\text { anda inginkan }\end{array}$} & Pilihan ganda & 11 & \multirow[t]{3}{*}{23} \\
\hline & & Benar Salah & 10 & \\
\hline & & Jawaban lain & 2 & \\
\hline
\end{tabular}

Sumber : diolah penulis, 2017

Berdasarkan tabel 9 dapat diketahui kebutuhan isi atau materi media pembelajaran interaktif Pasar Modal yang diinginkan oleh dosen. Pada indikator pertama yang berkaitan dengan cara penyampaian atau pemaparan materi, dapat diketahui bahwa dari 23dosen, 20dosen menyarankan agar materi disampaikan dengan uraian sejelas-jelasnya dan 3dosen menyarankan 
I-Economic Vol.4. No 1. Juni 2018

Analisis Kebutuhan Pengembangan Laboratorium .... Mawardi

cara lain, yaitu penjelasan yang disertai contoh penerapan. Berdasarkan hasil angket kebutuhan dosen tersebut, maka cara penyampaian materi yang diinginkan oleh dosen adalah penjelasan yang sejelas-jelasnya.

3) Kebutuhan Aspek Komunikasi Visual (Tampilan) Media Pembelajaran Interaktif Pasar Modal

Gambaran tentang aspek komunikasi visual (tampilan) media pembelajaran laboratorium Pasar Modal dapat dilihat pada tabel 10 berikut.

\section{Tabel 10 Aspek Komunikasi visual (tampilan) media pembelajaran}

\section{laboratorium Pasar Modal}

\begin{tabular}{|c|c|c|c|c|c|}
\hline No & Indikator & Pertanyaan & Pilihan Jawaban & $\begin{array}{l}\text { Jumlah } \\
\text { Jawaban }\end{array}$ & $\begin{array}{l}\text { Jumlah } \\
\text { Dosen }\end{array}$ \\
\hline \multirow[t]{3}{*}{1} & \multirow[t]{3}{*}{ Tampilan Warna } & \multirow{3}{*}{$\begin{array}{lcr}\text { Warna } & \text { yang } & \text { anda } \\
\text { inginkan } & \text { di dalam } \\
\text { media } & \text { pembelajaran } \\
\text { Pasar Modal }\end{array}$} & $\begin{array}{l}\text { Warna - warna cerah yang } \\
\text { tidak mengacaukan } \\
\text { tampilan }\end{array}$ & 23 & 23 \\
\hline & & & $\begin{array}{l}\text { Warna - warna gelap yang } \\
\text { tidak mengacaukan } \\
\text { tampilan }\end{array}$ & - & \\
\hline & & & Jawaban lain & - & \\
\hline \multirow[t]{3}{*}{2} & \multirow{3}{*}{$\begin{array}{l}\text { Adanya musik atau } \\
\text { efek suara }\end{array}$} & \multirow{3}{*}{$\begin{array}{l}\text { Apakah di dalam } \\
\text { media tersebut perlu } \\
\text { ada music pengiring }\end{array}$} & Sangat perlu & 3 & 23 \\
\hline & & & Perlu & 20 & \\
\hline & & & Tidak perlu & - & 23 \\
\hline \multirow[t]{3}{*}{3} & \multirow{3}{*}{ 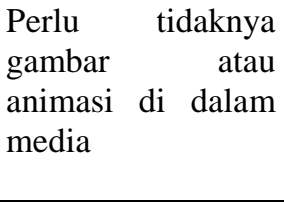 } & \multirow{3}{*}{$\begin{array}{lcr}\text { Apakah } & \text { di } & \text { dalam } \\
\text { media } & \text { pembelajaran } \\
\text { Pasar } & \text { Modal } & \text { perlu } \\
\text { disertai } & \text { gambar } & \text { atau } \\
\text { animasi } & & \end{array}$} & Sangat perlu & 5 & 23 \\
\hline & & & Perlu & 16 & \\
\hline & & & Tidak perlu & 2 & \\
\hline \multirow[t]{4}{*}{4} & \multirow{4}{*}{$\begin{array}{l}\text { Penggunaan huruf } \\
\text { dalam penyajian }\end{array}$} & \multirow{4}{*}{$\begin{array}{l}\text { Jenis huruf yang anda } \\
\text { inginkan untuk } \\
\text { menyajikan materi }\end{array}$} & Comic sans MS & 4 & 23 \\
\hline & & & Tahoma & - & \\
\hline & & & Times New Roman & 19 & \\
\hline & & & Jawaban Lain & & \\
\hline \multirow[t]{3}{*}{5} & \multirow{3}{*}{$\begin{array}{l}\text { Ketersediaan menu } \\
\text { atau ikon untuk } \\
\text { membantu } \\
\text { mahasiswa }\end{array}$} & \multirow{3}{*}{$\begin{array}{l}\text { Pendapat anda jika } \\
\text { disusun menu atau ikon } \\
\text { untuk membantu } \\
\text { belajar Mahasiswa }\end{array}$} & Sangat setuju & 16 & 23 \\
\hline & & & Setuju & 7 & \\
\hline & & & Kurang setuju & - & \\
\hline
\end{tabular}

Sumber : diolah penulis, 2017

Berdasarkan tabel 10 dapat diketahui aspek komunikasi visual (tampilan) media pembelajaran Pasar Modal yang diinginkan oleh dosen.Pada indikator pertama yang berkaitan dengan penggunaan warna, dapat diketahui bahwa 23 dosen memilih warna-warna cerah.Berdasarkan hasil tersebut, dapat disimpulkan bahwa karakter warna yang diinginkan 
I-Economic Vol.4. No 1. Juni 2018

Analisis Kebutuhan Pengembangan Laboratorium .... Mawardi

dosen di dalam media pembelajaran laboratorium Pasar Modal adalah warna-warna cerah yang tidak mengacaukan tampilan dan memberikan kenyamanan bagi mahasiswa.

\section{4) Aspek Kebutuhan Fisik Media Pembelajaran Laboratorium Pasar Modal}

Analisis aspek kebutuhan fisik media pembelajaran Pasar Modal ini merupakan gambaran kemasan fisik yang meliputi program Pasar Modal, karakter warna pada kemasan media pembelajaran Pasar Modal. Untuk memperoleh gambaran tentang aspek kebutuhan fisik media pembelajaran interaktif Pasar Modal dapat dilihat pada tabel 11 berikut:

Tabel 11 Kebutuhan Fisik Media Pembelajaran Pasar Modal

\begin{tabular}{|c|c|c|c|c|c|}
\hline No & Indikator & Pertanyaan & Pilihan Jawaban & $\begin{array}{c}\text { Jumlah } \\
\text { Jawaban }\end{array}$ & $\begin{array}{c}\text { Jumlah } \\
\text { Dosen }\end{array}$ \\
\hline \multirow[t]{4}{*}{1} & \multirow{4}{*}{$\begin{array}{lr}\text { Tampilan } & \text { Program } \\
\text { Trading } & \text { Online } \\
\text { Pasar Modal } & \end{array}$} & \multirow{4}{*}{$\begin{array}{l}\text { Bagaimana tampilan } \\
\text { program trading online } \\
\text { Pasar Modal }\end{array}$} & $\begin{array}{l}\text { Mempelajari Pasar Modal } \\
\text { asyik dan menarik }\end{array}$ & 11 & 23 \\
\hline & & & $\begin{array}{ll}\text { Buktikan bahwa } & \text { belajar } \\
\text { Pasar } & \text { Modal } \\
\text { menyenangkan } & \\
\end{array}$ & 2 & \\
\hline & & & $\begin{array}{l}\text { Mudahnya berinvestasi di } \\
\text { Pasar Modal }\end{array}$ & 10 & \\
\hline & & & Jawaban lainnya & - & \\
\hline \multirow[t]{4}{*}{2} & \multirow{4}{*}{$\begin{array}{l}\text { Jenis trading online } \\
\text { yang digunakan }\end{array}$} & \multirow{4}{*}{$\begin{array}{l}\text { Jenis Trading } \\
\text { yang anda pilih untuk } \\
\text { digunakan }\end{array}$} & Saham & 20 & 23 \\
\hline & & & Reksadana & 3 & \\
\hline & & & Obligasi & - & \\
\hline & & & Jawaban Lainnya & - & \\
\hline \multirow[t]{4}{*}{3} & \multirow{4}{*}{$\begin{array}{l}\text { Waktu } \\
\text { online }\end{array}$} & \multirow{4}{*}{$\begin{array}{l}\text { Waktu yang digunakan } \\
\text { dalam trading online }\end{array}$} & Tepat sekali & 20 & 23 \\
\hline & & & Tepat & 3 & \\
\hline & & & Kurang Tepat & - & \\
\hline & & & Jawaban lain & - & \\
\hline \multirow[t]{4}{*}{4} & \multirow[t]{4}{*}{ Akun Dummy } & \multirow{4}{*}{$\begin{array}{l}\text { Apakah perlu akun } \\
\text { dummy untuk pelatihan } \\
\text { mahasiswa }\end{array}$} & Sangat perlu & 20 & 23 \\
\hline & & & Perlu & 3 & \\
\hline & & & Tidak perlu & - & \\
\hline & & & Jawaban Lain & - & \\
\hline
\end{tabular}

Sumber : diolah penulis, 2017

Tabel 11 mendeskripsikan tentang aspek kebutuhan fisik media pembelajaran interaktif laboratorium Pasar Modal yang diinginkan oleh mahasiswa. Berdasarkan tabel 11 dapat diketahui bahwa, indikator pertama yang berkaitan dengan Tampilan Program Trading online Pasar Modal bahwa 11 dosem memilih judul Mempelajari Pasar Modal dengan Asyik dan Menarik, 2 dosen memilih Buktikan Bahwa Belajar Pasar Modal itu Menyenangkan, 10 dosenmemilih Mudahnya berinvestasi di Pasar Modal. Berdasarkan hasil tersebut, tampilan program yang diinginkan oleh sebagian besar dosen adalah Mempelajari Pasar Modal dengan Asyik dan Menarik. 
I-Economic Vol.4. No 1. Juni 2018

Analisis Kebutuhan Pengembangan Laboratorium .... Mawardi

A. Pengembangan Laboratorium Capital Market terpadu Prodi Perbankan Syariah menuju investor keuangan di usia muda Fakultas Ekonomi dan Bisnis Islam UIN Raden Fatah Palembang

1. Pengembangan Laboratorium melalui Program dari Danareksa Sekuritas, Laboratorium Pasar Modal Fakultas Ekonomi dan Bisnis Islam UIN Raden Fatah bekerja sama dengan pihak sekuritas dalam hal ini danareksa sekuritas dan Bursa Efek Indonesia dalam menjalankan laboratorium Pasar Modal. Pihak sekuritas memberikan fasilitas fasilitas dalam mengakses trading online bagi mahasiswa Fakultas Ekonomi dan Bisnis Islam melalui akses program D'one. Bentuk dari pengembangan Laboratorium Capital Market adalah adanya kerjasama pihak fakultas Ekonomi dan Bisnis islam UIN Raden Fatah dengan Pihak Bursa Efek Indonesia dan Sekuritas dalam hal ini danareksa sekuritas sebagi sekuritas yang mendukung mahasiswa dalam pembukaan account dan memberikan program di Laboratorium Pasar modal.

2. Pengembangan Laboratorium Pasar Modal melalui Galeri Investasi, Galeri Investasi Bursa Efek Indonesia (BEI) adalah sarana untuk memperkenalkan Pasar Modal sejak dini kepada dunia akademisi. Galeri Investasi BEI berkonsep 3 in 1 yang merupakan kerjasama antara BEI, Perguruan Tinggi dan Perusahaan Sekuritas diharapkan tidak hanya memperkenalkan Pasar Modal dari sisi teori saja akan tetapi juga prakteknya. Kedepannya melalui Galeri Investasi BEI yang menyediakan real time information untuk belajar menganalisa aktivitas perdagangan saham, diharapkan dapat menjadi jembatan menuju penguasaan ilmu pengetahuan beserta prakteknya di pasar modal.

\section{Prosedur Pendirian Galeri Investasi BEI di Perguruan Tinggi}

Tahap I : Penjajakan Pendirian Galeri Investasi BEI, Diawali dengan surat menyurat, penyampaian proposal \& profil Perguruan Tinggi yang dilanjutkan dengan pembahasan untuk mengetahui komitmen Perguruan Tinggi. Studi kelayakan mengenai potensial Perguruan Tinggi untuk mendirikan Galeri Investasi BEI, salah satunya adalah daya tampung dan kapasitas kampus. Penentuan Lokasi oleh pihak kampus yang memiliki lokasi Galeri Investasi BEI yang strategis.

Tahap II : Pendirian Galeri Investasi BEI, Pembuatan MoU Galeri Investasi BEI Dalam proses pendirian, persiapan awal pendirian adalah dengan menyiapkan sebuah MoU pendirian. 
I-Economic Vol.4. No 1. Juni 2018

Analisis Kebutuhan Pengembangan Laboratorium .... Mawardi

Tahap III : Peresmian Galeri Investasi BEI, Tahapan ini menggambarkan tentang proses persiapan acara peresmian beroperasinya Galeri Investasi BEI.

Tahap IV : Pembentukan KSPM (Kelompok Studi Pasar Modal) FEBI UIN RF, Tahapan ini bertujuan untuk menciptakan SDM yang mampu berorganisasi, bersosialisasi dan beradaptasi dilingkungannya yang diharapkan mampu mengembangkan dan memajukan potensi ekonomi, serta menciptakan SDM yang handal dibidang pasar modal. KSPM berfungsi sebgai wadah komunikasi, aktifitas, dan koordinasi bagi mahasiswa, dan melaksanakan serta mengembangkan kegiatan bersifat keilmuan dibidang pasar modal.

\section{SIMPULAN}

Berdasarkan uraian hasil penelitian dapat dikemukakan simpulan sebagai berikut :

1. Analisis Kebutuhan terhadap media pembelajaran capital market bagi mahasiswa dan dosen menginginkan media tersebut menjadi Menarik, yaitu disertai dengan gambar dan musik pengiring, Materi yang disajikan di dalam media disesuaikan dengan kebutuhan dan kompetensi dasar yang dipelajari mahasiswa dengan penyajian yang singkat dan jelas; dan Adanya contoh penerapan dan soal evaluasi.

2. Pengembangan Laboratorium Capital Market terpadu melalui pembuatan program yang bekerjasama dengan pihak Danareksa sekuritas, pembentukan Galeri Investasi bekerjasama dengan pihak Bursa Efek Indonesia dan pembuatan modul.

\section{DAFTAR PUSTAKA}

Abdul Manan, Aspek Hukum Dalam Penyelenggaraan Investasi di Pasar Modal, Jakarta: Kencana Prenada Media Group, 2009

Agni,AN.,Waskito F.,Suryadi E.,Hadiyanto T.,Budihardjo S.,Kanapsiah M, Skill's Lab,Bagian Pendidikan Kedokteran UGM,Yogyakarta , 2000.

Anti Damayanti dan Isma Kurniatanty, Manajemen \& Teknik Laboratorium, (Yogyakarta: Prodi Biologi, Fakultas Saintek, UIN SUKA, 2008)

Cambridge University Press, Cambridge Advanced Leaner's Dictionary, (Singapore: Green Gian Press, 2008) 
I-Economic Vol.4. No 1. Juni 2018

Analisis Kebutuhan Pengembangan Laboratorium .... Mawardi

Christian Setiawan, Persepsi Mahasiswa Program Manajemen Keuangan Terhadap Keberadaan Laboratorium Sebagai Fasilitas Penunjang Proses Belajar Mengajar,Universitas Kristen Petra FINESTA Vol. 3, No. 1, (2015)

Erna Hayati A.A Istri Agung Trisnawati Widyaiswara (2015), Analisis Kebutuhan pelatihan bagi petugas laboratorium penguji kualitas air dinas kesehatan kabupaten / kota seProvinsi Nusa Tenggara Barat Tahun 2015, ISSN No. 1978-3787 Media Bina Ilmiah 1 http://www.lpsdimataram.com Volume 9, No. 2, April 2015

Iskandar Wiryokusumo, Msc, Drs. J. Mandilika, Ed, Kumpulan-KumpulanPemikiran dalamPendidikan (Jakarta: CV. Rajawali, 2004)

Iswi Hariyani, R. Serfianto, Buku Pintar Hukum Bisnis Pasar Modal, Jakarta: Visimedia, 2010,

Koesmaji, W, dkk. Teknik Laboratorium. (Bandung: Jurusan Pendidikan Biologi FMIPA UPI,2004)

Made Agus Dharmadi1, I Made Satyawan2, Ni Luh Putu Tuti Ariani (2013), Studi analisis kebutuhan pengembangan buku panduan keselamatan dalam pembelajaran penjasorkes di SMA dan SMK Kebupaten Buleleng, ISSN: 2303-288X Vol. 2, No. 1, April 2013 jurnal Pendidikan Indonesia

Mulasiwi, Santosa, Pengembangan buku panduan praktik Laboratorium Bank Mini dalam rangka meningkatkan keterampilan pencatatan transaksi keuangan pada program keahlian Akuntansi, Jurnal Pendidikan Insan Mandiri Vol 1 No 1 (2016).

Mustaji, Laboratorium: Perspektif Teknologi Pembelajaran, Disajikan dalam Workshop Penyusunan Panduan Penggunaan Laboratorium di Fakultas Ilmu Pendidikan Universitas Negeri Surabaya pada hari Rabu, 23 Desember 2009.

Notoatmodjo. S,.Promosi Kesehatan dan Ilmu Perilaku Kesehatan,Rineka Cipta, Jakarta, 2012

Rai sujinam.Proceedings Seminar Nasional FMIPA UNDIKSHA V Tahun 2015

Sugiyono. Metode Penelitian Kuantitatif Kualitatif dan R\&D. Bandung: Alfabeta.2012

Tandelilin, Portofolio dan Investasi, Teori dan Aplikasi, Edisi Pertama, Penerbit Kanisius, 2010 